Tohoku J. exp. Med., 1975, 115, 223-225

\title{
Change of Pyrophosphatase Activity in the Chicken Serum during the Course of Development
}

\author{
Nobuo IsHIHARA \\ Department of Hygiene, Tohoku University School of Medicine, \\ Sendai
}

\begin{abstract}
IstrHara, N. Change of Pyrophosphatase Activity in the Chicken Serum during the Course of Development. Tohoku J. exp. Med, 1975, 115 (3), 223-225 - The change of pyrophosphatase activity in the chicken serum was studied during the course of development. The enzyme activity was higher at the age of rapid growth than at the age of maturation. This finding suggests the participation of pyrophosphatase and pyrophosphate in controlling the calcification process. - pyrophosphate; pyrophosphatase; development; calcification; Gallus domestica
\end{abstract}

Although high phosphatase activity was detected by Robinson (1923) in the preosseus cartilage of young rats, all efforts to implicate this phosphatase activity with calcification process have been unsuccessful (Mclean and Urst 1955).

Cartier and Picard (1955a, b, c and d) reported that most of the phosphorus content in the cartilage and bone of a rachitic rat was in the form of pyrophosphate. Based on the results of in vitro experiments with rats Parkins and Walker (1958) proposed that in the normal bone small portion of the total phosphate was in the form of pyrophosphate, and that the rachitic cartilage incubated in the calcifying medium did not contain pyrophosphate. Yendt et al. (1955) reported that the serum of renal ricket patients contains some unidentified substance which inhibits calcification of the rachitic rat cartilage in vitro. From human urine Fleisch and Bisaz (1961) isolated this inhibitory substance and identified it to be pyrophosphate. In hypophosphatasia with the retarded calcification of bone (Russel 1965) urinary pyrophosphate level was higher than in the healthy. These observations, together with the results from in vitro experiments by Fleisch et al. (1964a and b; 1967), suggest that in vivo pyrophosphate and, therefore, the pyrophosphatase activity play an important role in controlling calcification.

This paper reports a close correlation of serum pyrophosphatase activity with growth of the chicken in support of this hypothesis.

\section{Materials and Methods}

Male chicken of white leghorn, Gallus domestica, were used for experiments. They were brought to the laboratory 1 day after hatching, kept in an air-conditioned room (temperature, $30^{\circ} \mathrm{C}$; relative humidity, $75-80 \%$ ) for about three weeks, and were fed com-

Received for publication, November 22, 1974. 
mercial chiken food and water ad libitum. The blood samples from carotid arteries of 5 or 15 birds were pooled in a flask, heparinized, and centrifuged at $3000 \mathrm{rpm}$ for $15 \mathrm{~min}$ to separate serum. The serum was used for experiments without any dilution.

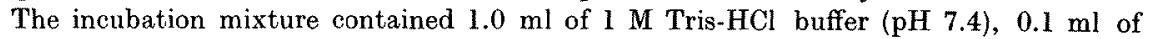
$0.05 \mathrm{M}$ sodium pyrophosphate, and $0.1 \mathrm{ml}$ of $0.01 \mathrm{M} \mathrm{MgCl}_{2}$. Reaction was initiated by the addition of $0.2 \mathrm{ml}$ or $0.4 \mathrm{ml}$ of serum, and carried out aerobically at $30^{\circ} \mathrm{C}$ for 20 , 40, and $60 \mathrm{~min}$, and was terminated by the addition of $0.75 \mathrm{ml}$ of $20 \%$ (W/V) trichloroacetic acid (TCA). To estimate the nonenzymic hydrolysis of pyrophosphate and carry-in of inorganic phosphate with the serum used as enzyme source, another incubation was carried out simultaneously omitting serum, and terminated by the simultaneous addition of 0.2 $\mathrm{ml}$ or $0.4 \mathrm{ml}$ of serum and $0.75 \mathrm{ml}$ of $20 \%(\mathrm{~W} / \mathrm{V}) \mathrm{TCA}$. In this way the sum of inorganic phosphate in the added serum and that formed by the nonenzymic hydrolysis of pyrophosphate was obtained. After the termination of the reaction, the incubation mixture was centrifuged at $3000 \mathrm{rpm}$ for $15 \mathrm{~min}$, and inorganic orthophosphate in the supernatant solution was determined by the method described by Takahashi (1955). In an preliminary experiment with several phosphorus compounds such as ATP, ADP, phosphoenolpyruvate, glucose-6-phosphate, creatine phosphate pyrophosphate, and inorganic orthophosphate, it was confirmed that this method is specific for inorganic orthophosphate.

\section{Results and Discussion}

As shown in Fig. 1, the pyrophosphatase activity in serum gradually increased from the 2 nd day after hatching to reach a maximum level at the age of 13th day, and thereafter turned to decrease to the level of adult roosters at the age of 35 th day after hatching. At the age of $6,9,22,30$ and 38 days after hatching the total protein concentration in the serum was in the range of 3.0 to $3.4 \mathrm{~g} / 100$ $\mathrm{ml}$, and the hematocrit value was between 28.6 and $31.8 \%$, indicating that the change of the pyrophosphatase activity observed (Fig. 1) was not attributable to the variation of serum protein concentration.

A hypothesis was proposed by several authors (Parkins and Walker 1958;

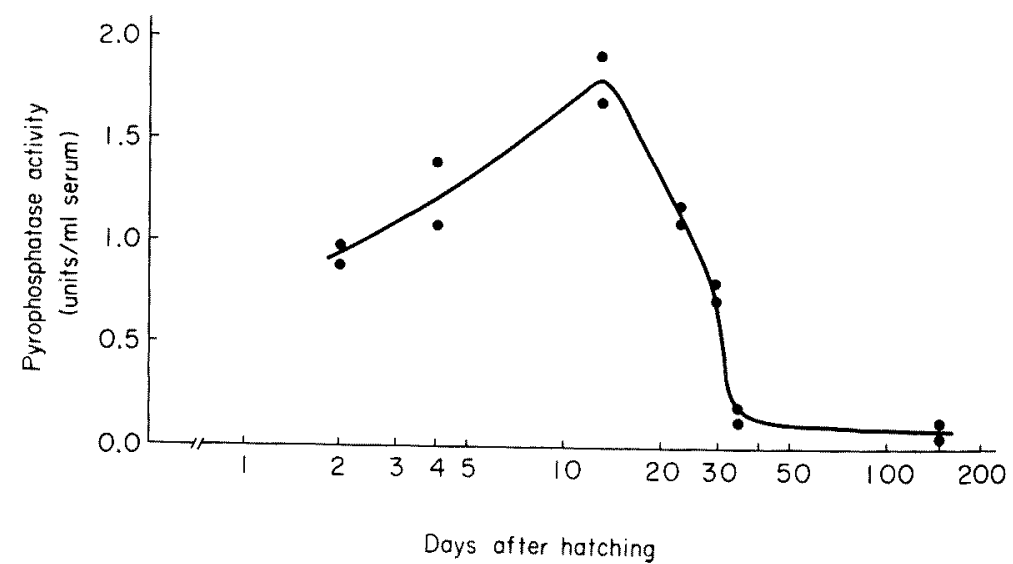

Fig. 1. Change of pyrophosphatase activity in the serum. Each value is the increment over the tissue blank and is the mean of duplicate incubations. One unit of the pyrophosphatase activity represents the activity which produces $1 \mu$ mole of inorganic orthophosphate in $20 \mathrm{~min}$ under the incubation conditions employed. 
Fleisch and Bisaz 1961; Fleisch et al. 1964a and b, 1967; Russel 1965; Eaton and Moss 1967) that pyrophosphatase removes the inhibitory effect of pyrophosphate on calcification process by hydrolyzing the phosphorus compound. The data shown in Fig. 1 are in accord with this hypothesis since it is expected that in the chicken at the age of 2 to 30 days after hatching the calcification process should be accelerated to cope with rapid growth. It is also expected that the pyrophosphate levels in the serum and cartilage may be far lower in the young chicken than in the adult rooster. Further experiments are in progress to elucidate this problem.

\section{Acknowledgment}

I wish to thank Dr. T. Watanabe, Department of Hygiene, Tohoku University School of Medicine, for his determination of serum protein concentration and hematocrit value.

\section{References}

I) Cartier, P. \& Picard, J. (1955a) La minéralisation du cartilage ossifiable: I. La minéralisation du cartilage in vitro. Bull. Soc. chim. biol. (Paris), 37, 485-494.

2) Cartier, P. \& Picard, J. (1955b) La minéralisation du cartilage ossifiable: II. Le systéme ATPasique du cartilage. Bull. Soc. chim. biol. (Paris), 37, 661-675.

3) Cartier, P. \& Picard, J. (1955c) La minéralisation du cartilage ossifiable: III. Le mécanisme de la réaction ATPasique du cartilage. Bull. Soc. chim. biol. (Paris), 37, 1159-1168.

4) Cartier, P. \& Picard, J. (1955d) La minéralisation du cartilage ossifiable: IV. La signification de la réaction ATPasique. Bull. Soc. chim. biol. (Paris), 37, 1169-1176.

5) Eaton, R.H. \& Moss, D.W. (1967) Alkaline orthophosphatase and inorganic pyrophosphatase activities in human serum. Nature (Lond.), 214, 842-843.

6) Fleisch, H. \& Bisaz, S. (1961) Isolement dans l'une substance inhibant la calcification: le pyrophosphate. Helv. physiol. pharmacol. Acta, 19, C69-C70.

7) Fleisch, H., Russel, R.G.G. \& Straumann, F. (1967) Effect of pyrophosphate on hydroxyappatite and its implication in calcium homeostasis. Nature (Lond.), 212, 901-903.

8) Fleisch, H., Schiebler, D., Maerki, J. \& Frossard, I. (1964a) Hemmung der bei der Ratte mit Vitamin $\mathrm{D}_{3}$ erzeugten Aortenverkalkung durch langekettige Polyphosphate. Helv. physiol. pharmacol. Acta, 22, C119-C121.

9) Fleisch, H., Straumann, F., Schenk, R., Bisaz, S., Frei, E., Maerki, J. \& Allgöwer, M. (1964b) Der Einfluss von Polyphosphaten auf die Verkalkung in vitro gezüchteter Knochen. Helv. physiol. pharmacol. Acta, 22, C71-C72.

10) Mclean, F.C. \& Urst, M.R. (1955) Bone. An Introduction to the Physiology of Skeletal Tissue, University of Chicago Press, Chicago, p. 58.

11) Parkins, H.R. \& Walker, P.G. (1958) The occurrence of pyrophosphate in bone. J. Bone Jt. Surg., 40B, 333-339.

12) Robinson, R. (1923) The possible significance of hexophosphoric esters in ossification. Biochem. J., 17, 286-293.

13) Russel, R.G.G. (1965) Excretion of inorganic pyrophosphate in hypophosphatasia. Lancet, 1, 461-464.

14) Takahashi, T. (1955) On the estimation of inorganic orthophosphate and creatine phosphate and the evaluation of phosphoamidase activity and creatine phosphokinase activity in the porcine sperm. Seikagaku (Jap.), 26, 690-698.

15) Yendt, E.R., Conner, T.B. \& Howard, J.E. (1955) In vitro calcification of rachitic rat cartilage in normal and pathologic human sera with some observations on the pathogenesis of renal rickets. Bull. Johns Hopk. Hosp., 96, 1-19. 